\title{
Hirudotherapy from Past to Present
}

\author{
Berrin Okka
}

Ass. Prof.Dr., Necmettin Erbakan University Meram Faculty of Medicine, Department of Medical History and Ethics, Konya-TURKEY

Eur J Basic Med Sci 2013;3(3): 61-65

Received: 28-10-2013

Accepted: 29-10-2013

Correspondence (Yazıșma Adresi): Ass. Prof. Dr. Berrin Okka Necmettin Erbakan University Meram Faculty of Medicine, Department of Medical History and Ethics 42080 - Konya, Turkey phone: +90332 2236988

Fax: +90 3322236181

E-mail: berrinokka@gmail.com

\begin{abstract}
Hirudotherapy which means the use of leech therapy dates as far back as 2500 years ago when they were used for bloodletting in ancient Egypt. During the Roman Era, Galen (130- 201 AD) used leeches because he believed that blood letting would rid the unbalance of the four humours (blood, phlegmon, black and yellow bile) in the human body. Leech treatments were very popular during the Middle Ages as applied by Ibn Sina (Avicenna). In his book "Al-Qanun Fi Al-Tibb (the Canon of Medicine)", Avicenna (980-1037 AD) gave detailed knowledge about leech therapy and instructions on leeching. Hirudotherapy was commonly practiced in the 1800 's by French physicians treating a variety of diseases. The medicinal leech has been used by plastic surgeons in recent years. They use leeches to relieve venous congestion, especially in transplant surgery. The leech produces a number of substances especially hirudin, calin, hylarunidase, histamine like vasodilators during biting. These substances are responsible for inhibiting blood coagulation, analgesic effect, dilating effect on muscles and regulation on immune system. The aim of this study was to explore the history and therapeutic applications of leech therapy from ancient times to present.
\end{abstract}

Key Words: Leech therapy, hirudotherapy, blood letting

\section{Geçmișten Günümüze Sülük Tedavisi}

ÖZET

Sülükle tedavi anlamına gelen hirudoterapi yönteminin bundan 2500 yıl öncesinde antik Mısır'da kan alma yöntemi olarak kullanıldı̆̆ı bilinmektedir. Roma döneminde Galen (M.S. 130-201) insan vücudundaki dört sıvının (kan, flegmon, sarı ve kara safra) dengesizliğinde kan almanın gerekli olduğuna inanarak sülük kullanmıştır. İbn-i Sina'nın da uyguladığı bir yöntem olarak sülük tedavisi Ortaçağ döneminde de çok popüler olmuștur. İbn-i Sîna (M.S. 980-1037) El Kanun Fi't-Tıbb adlı eserinde sülük tedavisi ve uygulama yöntemleri ile ilgili detaylı bilgiler vermiștir. Hirudoterapi, 1800'lü yıllarda Fransız doktorlar tarafından birçok hastalığın tedavisi için kullanılmıștır. Son yıllarda ise tıbbi sülükler plastik cerrahlar tarafından kullanılmaktadır. Özellikle transplantasyon cerrahisinde venöz konjesyonu azaltmak için sülük kullanılmaktadır. Sülükler kan emerken vücuda salgıladıkları sıvı özellikle hirudin, calin, hyalürinidaz ve histamin benzeri vazodilatör maddeleri 
içerir. Bu maddeler kanın pıhtılaşmasını engelleyici antikoagülan özelliğe, ağrı kesici, kas gevșetici, bağıșıklık sistemini düzenleyici etkiye sahip oldukları kabul edilmektedir. Çalıșmamızın amacı, antik dönemlerden günümüze sülükle tedavinin tarihini araștırmaktır.

Anahtar Kelimeler: Sülük tedavisi, hirudoterapi, kan almak

\section{INTRODUCTION}

Blood-letting was one of the oldest and common therapeutic methods in Mesopotamian, Egyptian, Greek, Greco-Roman and Byzantine medicine. The methods used for this purpose were cupping, venesection and application of leeches. Each method was used in different conditions, depending on the sufficient amount of blood to be removed and the certain important organs affected (1). Leech therapy has used for the treatment of a lot of diseases since ancient times. Leech is derived from the Anglo-Saxon word "laece" which, means "physician" $(2,3)$. Hirudotherapy" which is called leech therapy in Latin, is a means of treatment used by physicians for ages. The first use of leeches for medical purposes can be seen in the wall paintings of an Egyptian tomb (1567$1308 \mathrm{BC}$ ). The first written record of their medicinal use has been attributed to Nicander of Colophain (200$130 \mathrm{BC}$ ) in his medical poem "Alexipharmaca" (2). The therapeutic use of leeches has also been reported by Themison of Laodicea, a pupil of Asclepiades in the year $50 \mathrm{BC}$ (4). The physician Pliny (23-79 AD) states that it provides relief for the person by removal of the excessive blood from the human body, and also indicates the methods of leech application $(5,6)$.

Galen, during the Roman period (130- $201 \mathrm{AD}$ ), indicated the use of leeches, its application methods, the removal of the leech from the body, the treatment of any bleeding that might occur on the wound after leech sucked the blood. According to the humoral theory that Galen developed, the human body contains four fluids: blood, phlegm, yellow bile and black bile. He indicated that changes in the balance of these fluids cause diseases and leeches suck the excessive blood and provide the regeneration of the balance (7). In the same century, another physician Menemachus used leech therapy. Oribasius, a physician in the 4th century, applied the leech therapy. Oribasius, Paul of Aegina and Aetius of Amida reported in their works that Antylus, the surgeon, also applied the leech therapy $(1,8)$. Alexander of Tralles (525-605 $A D)$ suggested application of leeches in some hearing loss and the treatment of "melancholia". In antiquity, they recommended this therapy as they believed melancholia develops as a result of accumulation of black bile in the brain or the whole blood of flow (1). In the 6th century AD Aetius of Amida mentioned the leech application for the eye disease, which he called "onchia", creating a circle around the iris of the eye due to ulcer development in the deep layers of the eye. Aetius also recommended the use of leeches for the disorder, called "catharsis" that is caused by imbalance of body fluids, especially imbalance of blood (9). Paul of Aegina, in the 7th century, mentioned the application of leech in the treatment of many diseases. He benefited from the application of leeches especially for headaches that he called "cephalea" and eye disorders, known as "amourozis" and "'ophthalmy", and also inflammatory disease of the throat (10).

Ibn Sina (980-1037 AD) is a pioneer physician in Islamic Medicine and his famous book "Canon" was translated into Ottoman Turkish by Tokatlı Mustafa Efendi in 18th century. The manuscripts of this translation are to be found in the copy form in places as follows: Topkap Palace (IIlth Ahmet 1903); the Library of Süleymaniye, (Hamidiye 1015) and the Library of Ragip Pasa (1335) (11). One of the things he mentioned in this book is the diseases for which leech therapy is applied along with its methods of application. According to Ibn Sina (Avicenna) the application of leech is more useful than cupping in letting odd the blood from deeper parts of the body $(11,12)$. Ebul Kasım Zehravi (936-1013 AD) explained in his book, "Kitab-ul Tasrif", that cupping, bloodletting and leeching could be used for medicinal purpose. Leeches can be applied to the specific areas such as eye, lip, nose and gums where cupping can not be employed (13). As removal of the excessive blood was a commonly used method during the 17th and 18th centuries, leech therapy was also widely used. It was used for medicinal blood-letting and believed to cure a variety of diseases from gout to headaches (14). Surgeon Broussais (1772-1838) in Napoleon's army units recommended removal of blood from the body or leech therapy since he believed that any blood accumulation in the body causes inflammation and inflammation causes diseases $(15,16)$. French physicians even prescribed leech therapy for the patients admitted to hospitals without the need for examination. Leech therapy was applied 
without considering the diagnosis of the disease and the starting age of this treatment, side effects of it and the patient's health status. During the same period, as it was considered to be a popular method of treatment in European countries, in Britain and Russia, it was used for treatment of inflammatory diseases of brain tissue, liver and kidney diseases, certain ophthalmologic diseases, nose bleeding, rheumatism, tuberculosis, epilepsy and sexually transmitted diseases (17.) Leech shortages were reported in Europe during that time (14). It is known that leech therapy was used by physicians in the Ottoman period and a great many written works are available especially in the 18th century (18). Serefeddin Sabuncuoglu was a famous Ottoman surgeon and physician. He was the author of Cerrahiyyetu'l - Haniyye (Imperial Surgery), the first illustrated Turkish-written surgical atlas. The leech therapy was described in his book (19). Sanizade Mehmet Ataullah Efendi (17711826), in his work" Mi'yaru'l Etibba ', recommended leech therapy to the back of ear for fever treatment, which developed in children during tooth growth (20). At the end of the 19th century, with the trend of experimental methods, practicing this method was outdated and it was regarded as quackery because unqualified persons had also applied it (21).

In 1884, Doctor John B. Haycraft called the pure anticoagulant substance, which he found in the saliva of leeches, "Hirudun" in Latin "Hirudo" (22). Since the second half of the 20th century, physicians especially micro surgeons have supported the use of leech again. On studies, based on observation, with the use of leech in the early period, it has been observed that there has been a noticeable improvement on the tissues which venous congestion has developed. Peer -reviewed evidence has proposed that venous congested flap is improved by early application of a leech $(23,24)$.

\section{Features of the Leeches}

Leeches are in class of Hirudinea of Annelida of helmints. There are more than 650 known species. One of the most popular medicinal leeches, Hirudo medicinalis, may be living in fresh waters and its length is nearly 10 $\mathrm{cm}$. When the anatomies of leeches are examined, it can be seen that their body is composed of fixed number, 34 segments and their body shapes are in dorsa-ventral flat. Hirudo medicinalis has two suckers: one present anteriorly on the head, and the other on the posterior end. The mouth lies in the anterior sucker and has three jaws with the teeth well designed for biting. The leech can ingest blood almost ten times its own weight $(17,25)$. Substance of leech saliva is composed of therapeutic secretions. Leeches secrete bioactive substances to the body while sucking the blood. One of these substances is Hirudin, a polypeptide molecular, with 9000 molecules weight, is composed of 65 amino acids. Hirudin, with the anticoagulant property, can be used as "Heparin". It forms an enzyme inhibitory complex with thrombin, thus preventing conversion of fibrinogen to fibrin (12).

Antithrombin III is not required for activation of Hirudin unlike Heparin, and it is non-inactivated by Trombositfactor-4, which is secreted during coagulation. Hirudin is not interactivated with clothing proteins except for Thrombin. There is also no risk of hemolysis and internal organs bleeding. Other enzymes secreted by the salivary glands: vasodilator agents, hyaluronidase that is responsible for the diffusion allowing anticoagulant substance to spread around the wound, anti-inflammatory effective protease inhibitor bdellin, anti-inflammatory and antioxidant effective eglin, anti-elastase limiting elastase activity on cutaneous tissue, destabilaz involved in dissolving blood clots, platelet aggregation inhibiting substances such as Calin $(14,17)$. Leech salivary gland secretions are also a matter of local anesthetic (26).

\section{Application of Leech Therapy}

Application area should be thoroughly cleaned with water so that leech can stick to. Sugared water or milk can be poured to the desired region or, a small scratch can be formed with the tip of the injector or lancets. With the help of forceps, leech can be taken out of the jar and laid upon the desired location. Leech is usually saturated in 15 to 20 minutes. Despite a long period of time, when attached leeches do not leave, pulling them away can be extremely dangerous. The teeth of leech can stay in the place of its bite and can cause infection. With the help of cotton or cloth that is soaked in alcohol or saline, leech can be removed from host. By application of watery mug, the toxins can be removed (12). Saturated leech can be killed by putting it in $70 \%$ alcohol solution. Leeches used for one patient shouldn't be reapplied for another patient (27).

\section{Application Areas of Leech Therapy}

Leeches, since ancient times, have been used fort the treatment of various diseases, which is based upon the belief that excessive blood is absorbed. In modern medi- 
cine, leeches are used in orthopedics and traumatology as well as microvasculer reimplantation and reconstructive surgery (28). Leech therapy is also used for deep vein occlusion in legs, peripheral arterial occlusion, varicose veins and circulatory system diseases such as hemorrhoid. It is applied for some skin diseases, mainly eczema and psoriasis, burn cases, unhealed wounds and some surgery scars too. In free flap applications of plastic and reconstructive surgery, post-operative venous problems are more frequent especially compared with arterial problems. Leech is used in many countries to maintain local circulation to re-planted ear, lip, tip of nose, fingers and hairy skin that are broken apart in accidents as a result of venous insufficiency in surgical areas. Positive results have been obtained in the treatment of painful conditions such as various swelling caused by trauma, inflammation and hematoma. Leech therapy is performed for periodontal alveolar area and the drainage of dental abscesses. Experiments have been carried out in Meniere disease and tinnitus regarding ear, nose and throat (29-33).

\section{Complications of Leech Therapy}

The most common complication after leech therapy is prolongation of bleeding time. In this case, topical thrombin and pressure is applied for the treatment. In addition, allergic reactions to leech saliva and some bacterial infections may also occur (2). Allergic reactions, starting as simple itching can also be seen in the form of burning sensations and even worse, lead to the cause of ulcerative necrosis. These complications are the result of toxins found in the leech saliva (34). Infection may develop due to the re-use of leeches and scar tissue may exist due to the excessive use in the field of the treatment $(2,9)$.

\section{CONCLUSION}

Today, especially in the fields of re-constructive and $\mathrm{mi}$ cro-surgery, leeches are benefited for sustaining the vitality of the tissue and skin grafts that are under threat of venous congestion. Anticoagulant feature of Hirudin, found in leech saliva, is of great importance for treatment and prevention of thromboembolic disease. More experimental studies should be carried out in order to develop various application areas. The possible complications and hygiene should be paid attention to during the leech therapy.

\section{REFERENCES}

1. Papavramidou N, Christopoulou-Aletra H. Medicinal use of leeches in the texts of ancient Greek, Roman and early Byzantine writers. Intern Med J 2009; 39 (9): 624-7.

2. Wells MD, Ralp T, Manktelow RT, Boyd JE. Bowen V. The medical leech: an old treatment revisited, Microsurgery 1993; 14: 183-6.

3. Sawyer RT. Johann Frederick Diffenbach: Successful use of leeches in plastic surgery in the 1820s. British J Plast Surg 2000; 53: 245-7.

4. Cole D. Clinical hirudology: Revival of an ancient art. N Z Med J 1985; 98: 28-9.

5. Carter, K. Codell Leechcraft in the Nineteenth Century. Journal of the Royal Society of Medicine 2001; 94: 38-42.

6. Pliny the Elder. Natural History, Vol 8, translated by H. Rackham, Harvard University Press, London, W. Heineman. 1938: 547.

7. Galen 'On the natural faculties' translated by A.J. Brock, The Loeb Classical Library. Harvard University Pres, Cambridge. Massachusetts and William Heinemann, London, 1952.

8. Daremberg Ch. Oeuvres d'Oribase, Vol. 2. Paris Imprimeries Imperiale; 1884: 69-73.

9. Chalain TM. Exploring the use of the medicinal leech: a clinical risk-benefit analysis. J Reconstr Microsurgery 1996;12(3):165-72.

10. Adams F. The Seven Books of Paulus Aegineta, Vol I. London: Sydenham Society 1844: 302-421.

11. Ibn-i Sina, El-Kanun Fi't-Tıbb, Vol. 1, Translated by Esin Kahya. Atatürk Language and Culture Center, Ankara, 2009: 413-4.

12. Mory RN, Mindell D, Bloom DA. The leech and the physician: biology, etymology and medical practice with Hirudina medicinalis. World J Surg 2000; 24: 878-83.

13. Kaadan AN. The surgery of Al-Zahrawi, dar al-Qualam-Al Arabi, Aleppo, Syria, 1999: 318-44.

14. Munshi Y, I Ara, H Rafique and Z. Ahmad. Leeching in the history-a review. Pak. J. Biol. Sci 2008; 11: 1650-3.

15. Castiglioni A History of Medicine. Translated by Krumbhaar, E.B. 2nd ed. Knopf, New York 1947: 672-98.

16. Rolleston JD. Francois-Joseph-Victor Broussais 1772 to 1832: his life and doctrines. Proc R Soc Med 1959; 22: 405.

17. Adams S L. The medicinal leech. A page from Annelids of internal medicine. Ann Int Med 1988; 109:399-405.

18. Erdemir AD. Folklorik Tıpda Sülük Kullanımı ve Evrensel Gelișimi. İstanbul Üniversitesi Tıp Fakültesi Mecmuası 1979; 42:523-29.

19. Sabuncuoglu S. Cerrayetü'l Haniyye. Translated by I. Uzel Atatürk Kültür, Dil Tarih ve Yüksek Kurumu, Türk Tarih Kurumu Yayınları, Ankara 1992: 91-104. 
20. Acıduman A. Sanizade Mehmet Ataullah Efendi ve Mi'yaru'l Etibba adlı eserinde çocuk hastalıkları. Çocuk Sağlığı ve Hastalıkları Dergisi 2009; 52: 42-52.

21. Whitaker I S, Rao J,Izadi D,Butler PE. Historical Article: Hirudo medicinalis: ancient origins of the use of medicinal leeches throughout history. British Journal of Oral and Maxillofacial Surgery 2004; 42:133-7.

22. Haycraft JB. On the action of secretion obtained from the medicinal leech on coagulation of blood. Proc $R$ Soc London 1884; 36: 478.

23. Upshaw J, Oleary JP. The medical leech: past and present. Am Surgeon 2000; 66: 313-4.

24. Batchelor A G C, Davison P, Sully L. The salvage of congested skin flaps by the application of leeches. Br J Plast Surg 1984; 34: 358-60.

25. Faust EC, Russel PF, Jurg RC. Craig and Faust's Clinical Parasitology, 8 th ed. Philadelphia: Lea \& Febiger 1970: 563-70.

26. Anurag S, Ridhima S. A brief review on applications of leech therapy. Archives of Applied Science Research 2010; 2 :271-4.

27. Pantuck AJ, Lobis MR, Ciocca R, Weiss RE. Penile replantation using the leech Hirudo medicinalis. Urology 1996; 48: 953-6.
28. Weinfeld $A B$, Yuksel $E$, Boutros $S$, at al. Clinical and scientific considerations in leech therapy for the management of acute venous congestion: An updated review. Ann Plast Surg 2000; 45: 207-12.

29. Conforti ML, Connor NP, Heisey DM, at all. Evaluation of performance characteristics of the medicinal leech (Hirudo medicinalis) for the treatment of venous congestion. Plast Reconstr Surg 2002; 109(1): 228-35.

30. White S.S. History of dental and oral science in America. Published in American Academy of Dental Sciences. Philadelphia 1876: 75.

31. Hyson JM. Leech therapy: a history. J Hist Dent. 2005; 53(1): 25-7.

32. Frodel Jr, Barth P, Wagner J. Salvage of Partial facial soft tissue avulsions with medicinal leeches. Otolaryngol Head Neck Surg 2004; 131: 934-9.

33. Trovato MJ, Agarwal JP. Successful replantation of the ear as a venous flap. Ann Plast Surg 2008; 61: 164-8.

34. Itrat M, Zarnigar, Haque N. Historical aspects of leech therapy: a critical review. Int J Health Sci Res 2013; 3(7): 78-83. 